\title{
Commentary: Alternative Cultures in Planning Research--From Extending Scientific Frontiers to Exploring Enduring Questions
}

\section{Citation}

Forsyth, Ann. 2012. Commentary: Alternative Cultures in Planning Research--From Extending Scientific Frontiers to Exploring Enduring Questions. Journal of Planning Education and Research 32, no. 2: 160-168.

\section{Published Version}

doi:10.1177/0739456×12442217

\section{Permanent link}

http://nrs.harvard.edu/urn-3:HUL.InstRepos:12748041

\section{Terms of Use}

This article was downloaded from Harvard University's DASH repository, and is made available under the terms and conditions applicable to Other Posted Material, as set forth at http:// nrs.harvard.edu/urn-3:HUL.InstRepos:dash.current.terms-of-use\#LAA

\section{Share Your Story}

The Harvard community has made this article openly available.

Please share how this access benefits you. Submit a story.

\section{Accessibility}


Initial submission, August 2011; revised submissions, November 2011 and February 2012; final acceptance, February 2012

\section{Commentary: Alternative Cultures in Planning Research-From Extending Scientific Frontiers to Exploring Enduring Questions}

Ann Forsyth, Cornell University, Ithaca, NY, USA

\section{Corresponding Author}

Ann Forsyth, Department of City and Regional Planning, 106 West Sibley Hall, Cornell University, Ithaca, NY 14853, USA

Email: forsyth@cornell.edu

\section{Keywords}

education, methods, research

\section{Bio}

Ann Forsyth is a professor of City and Regional Planning at Cornell University. Her research interests focus on how to make more sustainable and healthy cities, with much of that research conducted in suburbs.

\footnotetext{
Abstract

As academic planning has grown and evolved, it has developed different ways of doing planning research. People may (a) work at the scientific frontier, (b) investigate issues of practical
} 
relevance, (c) reflect on the implications of practice, or (d) try to answer the enduring questions of planning. These are important differences. Different cultures represent varying ideas about what constitutes an important or significant contribution to the field of planning.

\section{Acknowledgments}

I would like to thank Kevin Krizek, Katherine Crewe, Michael Brooks, and three anonymous reviewers for their comments.

\section{Contributions in Planning}

As academic planning has grown and evolved, maturing within itself while also grasping new interdisciplinary opportunities, it has developed several different ways of doing planning research. This has occurred even as the $\mathrm{PhD}$ in planning has become more common as a basic qualification of the professorate, formerly drawn from a plethora of fields. There are of course many differences among planning researchers that have been the subject of substantial discussion either within planning or outside it. These include specific methods, interdisciplinary partners, theoretical approaches, planning specialties, ethical stances, and the relationship between the researchers and those they may be studying (Beauregard 2001; Birch 2001; Siemiatycki 2012).

Overlapping with these, however, is an additional set of important differences that affect the scope, form, intended audience, and perceived value of research products such as articles, books, talks, and other outputs produced by planning faculty. I call this dimension the research "culture" though it may be more precisely seen as a subculture. ${ }^{i}$ I identify four different cultures in planning — work on the scientific frontier, focused on practical relevance, demonstrating reflective practice, and engaging with enduring questions (including making provocative critiques of planning). Those from different research cultures have contrasting ideas about what 
constitutes an important or significant contribution to the field of planning. Disagreements among those from different cultures can lead to a great deal of misunderstanding and nastiness within diverse faculty groups such as planning departments and programs. This commentary is a plea for scholars to tolerate their colleagues' cultures better and in doing so to be more sophisticated judges of others' work.

This commentary examines the range of planning research cultures from frankly scientific papers to critiques of the possibility of science. Of course there is overlap between some of the categories and many people engage with two or more cultures. However, the differences are also important. For someone interested in enduring questions each carefully circumscribed scientific paper, or even group of papers, will seem overly narrow. For those worried about critical perspectives on enduring questions, practically-relevant research may seem to ignore underlying and unequal relations of power, logical inconsistencies, and the like. Those concerned about practical applications may find those working on the scientific frontier to be naïve about how to get things done.

Such diversity in cultures can be seen as a helpful sign of an intellectually active and engaged scholarly community, focused on dealing with a range of important topics using a variety of strategies. This kind of situation is common enough in other professional fields. However, it can also lead to a lack of appreciation for colleagues' contributions, marginalizing people and work within departments and schools.

Such misunderstandings may mean that scholars used to answering questions of one type may incorrectly assume that work of another type is of lower quality. They may be offended by even well-meaning and thoughtful questions about work from their favored culture, assuming others are unqualified to ask such questions. Of course, they may well have experienced illconceived attacks or had to deal with superficial questions in the past. Alternatively, colleagues 
may also retreat from making useful judgments about work from another culture, meaning that they do not distinguish between better and worse work. This can mean that poor quality work goes unquestioned.

This issue of culture is important because location still matters in the academic world. While it may seem that planning research networks are international, and therefore sympathetic peers are numerous, scholars are also located in specific places (Barnes 2004; Thrift 1999). Those local settings can affect research careers in substantial ways. This is placed in striking relief at key times in academic life when researchers are judged by departments rather than by like-minded specialists - for example, during faculty hiring and promotion. It is, however, present even outside those memorable and dramatic moments. Local decision makers such as department chairs and faculty committees set salary increases, allocate space, distribute administrative and teaching tasks, admit students with specific interests, and hire or dismiss potential faculty collaborators. It can make a big practical difference to a faculty member's work if one's research culture is valued by others in one's home department or program.

These differences between cultures are not, of course, the only kinds of scholarly disagreements. Those from the same research culture can disagree quite intensely about theory, methods, and how to interpret findings. This is to be expected. Others have conflict-seeking styles of interaction as part of their personalities. However, differences in culture are also important, particularly in intellectually diverse departments as is typically the case in planning.

This paper first provides an overview of some relevant concepts for examining intellectual cultures in scholarly fields such as how tightly knit fields are, how fast-paced and team-based research is, and whether researchers are insiders or outsiders. It then describes the four proposed cultures in planning, investigating some of their characteristics including the selfconcepts of those who do that kind of work and critiques by others. The paper then describes 
how differences in research and scholarship have been previously examined in urban planning and environmental design contrasting earlier work on styles of research (such as empirical studies or works of synthesis) with cultures. It concludes with suggestions for better dealing with this form of intellectual diversity in the planning academy. Overall, the exact research culture categories and examples are less important than the basic argument that one of planning's strengths is its interdisciplinarity and comprehensiveness. For departments and programs to grow and develop, however, planning faculty need to engage with others in a respectful yet robust way.

\section{Understanding Research Cultures}

For this argument it is important to understand what is meant by a number of key terms. First, this paper is about research in planning — not in other disciplines, and not about other tasks performed by academics, as important as they are. Many of the activities of planning academics, including research, fall into the category of scholarship. As one review has summarized, scholarship "demonstrates great expertise in a discipline, with clear goals and methods, documentation and internal critique, and broad significance as judged by peers" (Forsyth and Crewe 2006, p. 161; Diamond 2002). Faculty can, for example, have a scholarly approach to such activities as teaching or engagement (Boyer 1990; Checkoway 1998; Rice 2002). They can, of course, also engage in standard (non-scholarly) professional practice or administration.

Research is a subset of scholarship. Researchers, however, have to perform some tasks beyond the baseline of scholarship--to grapple with questions of broad interest, collect and analyze data systematically, build on earlier work, recognize alternative explanations, evaluate findings, make work public, and have "an overall goal of contributing to the knowledge base of the field" (Forsyth and Crewe 2006, 161; Hack 1984). As Hopkins (2001) explains, fields of 
inquiry also must have agreement about how to do research: "At any given time for any given field of inquiry, there must be agreement on a core of relevant causal mechanisms, agreement on stopping rules about what depth of explanation is sufficient, and agreement on criteria for better or worse explanations" (Hopkins 2001, 400; Barnes 2004). This paper is essentially arguing that there is currently agreement about how to do planning research within cultures but perhaps insufficient appreciation between cultures.

Becher and Trowler (2001) provide a review of several other important distinctions used by those examining research activities in particular disciplines. A basic distinction is between “convergent, tightly knit disciplinary configurations and those which are divergent and loosely knit" (Becher and Trowler 2001, 28; bold added). Academic planning is obviously the second, divergent, type with strong links to and collaborations with a number of related fields such as design, economics, geography, public health, law, and history. Many academic planners identify with those other fields by publishing in their journals and attending their conferences (Becher and Trowler 2001, 59). ${ }^{\text {ii }}$ This is important because some differences between research cultures in planning are to do with its divergent character, and mirror those between related disciplines. For example, Megill (1987) describes the "philosophy/history frontier" in terms that could easily be applied to the distinctions between research cultures in planning:

...philosophers, in their writing, are inclined to consider at great length matters that historians pass over quickly, and vice versa. Judged as philosophy, works of history are likely to seem weak. Judged as history, works of philosophy are likely to seem irrelevant. (quoted in Becher and Trowler 2001, 60)

Becher and Trowler (2001) draw on their own interviews with scholars from many fields to characterize a second important feature that distinguishes different subfields: the people-toproblem ratio. ${ }^{\text {iii }}$ This forms a continuum from high to low. At one end of the continuum are 
areas with a large number of researchers and a small number of research problems that can be examined in a relatively short period of time (as in many parts of big science and exemplified by the recent public health turn in planning). At the other end are subfields where only a few researchers engage with each problem and people essentially divide up the broad research territory with little overlap (as might be seen in planning history but also in some scientific subfields such as botanical taxonomy) (Swales 2004, 13). In areas where the people-(or researcher)-to-problem ratio is higher researchers typically need more funding; work in bigger research teams; communicate a great deal of substantive information via email, conference call, preprint, and the like; experience short lag times to publication; present relatively little background information in publications; cite few "foundational" publications; and generally write short papers (Becher and Trowler 2001, chapter 6; Swales 2004, 15). Those working in areas with a low people-to-problem ratio are the opposite. These are big differences.

Analysts also distinguish between levels of insider and outsider status in terms of the researcher and the subject of study. Social researchers generally are members of society, study society, and "present the results of their work to members of society;" that is the researcher, those they study, and research audiences overlap (Ragin 1994, 7). In sociological studies of science there is a great tension between the knowledge conferred by insider status as a scientist versus the critical distance attainable as an outsider (Latour 1981). Planning researchers experience this situation keenly; they may well not only be members of society but planning practitioners - traditional, activist, or some mix (Siemiatycki 2012).

Finally, some have attempted to categorize planning research, in broad terms, typically proposing two key poles or dimensions. (Classifications of different research methods or styles are dealt with at the end of the paper.) Hopkins (2001) distinguishes between incremental or cumulative versus integrative work (drawing together the big ideas from discoveries by others). 
He proposes that while people can become very visible or famous through integrative work, the field is advanced by "intentional efforts to develop threads of cumulative work" (p. 400; also Goldstein and Carmin 2006, 68). This perspective is not uncontroversial - the categories are broad and the idea of incremental work assumes that research is basically progressive (Barnes 2004; Kuhn 1962). However, it starts to indicate that there are different types of research contributions in planning.

This commentary also draws on two published studies that systematically assessed research styles or designs, surveying papers published in seven planning and design journals. One examined almost 40 years of publications in the Journal of the American Planning Association (JAPA) and the other reviewed six environmental design journals over a 10 year period (Goldstein and Carmin 2006; Forsyth and Crewe 2006; also DuToit 2010). Recent debates about the relationship between journal reputation, bibliometric measures such as impact factors, peer review, and contribution, while not specifically on this topic do provide an important background debate (Goldstein and Maier 2010; Punter and Campbell 2009; Salet and Boer 2011; Stiftel et al 2009). I have also published using different cultures, refereed over 250 articles and many more conference papers and books across all of the areas, judged best article in a major planning journal or a planning specialty area for five years, and listened to numerous critiques and defenses of work. This is a scholarly commentary reflecting on those various sources of data.

\section{Planning Research Cultures}

Conceptually, planning research cultures are not just points along a continuum but vary in a number of key dimensions, many related to concepts described above including the people-toproblem ratio and insider vs. outsider status. For example, work at the scientific frontier clusters toward the high end of the people-to-problem ratio and work assessing practice is found toward 
the low end. Work on the scientific frontier tends to be from something of an outsider perspective, that assessing practice takes more of an insider approach (including researchers reflecting on their own practice or studying practice qualitatively in depth). There are also many other related differences including project scope, funding, and norms of collaboration and authorship. Figure 1 summarizes a number of these differences usingexample questions from the area of planning for sustainability and articles from recent issues of the Journal of Planning Education and Research (JPER). ${ }^{\text {iv }}$

Do these research cultures cover all possible kinds of research in planning? This is unlikely. However they do cover a broad range of work produced by planning faculty. The following sections explain the differences between cultures in more detail. 
Figure 1: Characteristics of Cultures

\begin{tabular}{|c|c|c|c|c|c|c|}
\hline & $\begin{array}{l}\text { Example question / } \\
\text { topic }\end{array}$ & Typical Scope & $\begin{array}{l}\text { Single } \\
\text { Output } \\
\text { Length }\end{array}$ & External Funding & Authors & $\begin{array}{l}\text { Recent Journal of Planning Education and } \\
\text { Research }(J P E R) \text { Examples }\end{array}$ \\
\hline $\begin{array}{l}\text { Scientific } \\
\text { Frontiers }\end{array}$ & $\begin{array}{l}\text { Does increasing } \\
\text { residential density } \\
\text { decrease } \mathrm{C} 02 \\
\text { emissions--an } \\
\text { evaluation? }\end{array}$ & $\begin{array}{l}\text { One narrow } \\
\text { question per paper } \\
\text { (for scientific } \\
\text { journals); many } \\
\text { papers from one } \\
\text { project }\end{array}$ & $\begin{array}{l}\text { Short to } \\
\text { med. }\end{array}$ & $\begin{array}{l}\text { High; } \\
\text { productivity and } \\
\text { impact needed } \\
\text { for future funding }\end{array}$ & $\begin{array}{l}\text { Teams; } \\
\text { students } \\
\text { with minor } \\
\text { roles often } \\
\text { added }\end{array}$ & $\begin{array}{l}\text { - Raja and six colleagues (2010): Food } \\
\text { Environment, Built Environment, and } \\
\text { Women's BMI: Evidence from Erie } \\
\text { County, New York. } \\
\text { - Rayer \& Smith (2010): Factors Affecting } \\
\text { the Accuracy of Subcounty Population } \\
\text { Forecasts. } \\
\text { - Guhathakurta \& Gober (2010): Residential } \\
\text { Land Use, the Urban Heat Island, and } \\
\text { Water Use in Phoenix: A Path Analysis. }\end{array}$ \\
\hline $\begin{array}{l}\text { Practical } \\
\text { Applications }\end{array}$ & $\begin{array}{l}\text { How effective are } \\
\text { zoning ordinances } \\
\text { in dealing with } \\
\text { climate change? }\end{array}$ & $\begin{array}{l}\text { Multiple issues e.g. } \\
\text { current knowledge } \\
\text { + research evidence } \\
\text { + implications for } \\
\text { practice }\end{array}$ & Med. & $\begin{array}{l}\text { Varies; related to } \\
\text { practical } \\
\text { application }\end{array}$ & Varies & $\begin{array}{l}\text { - Muller \& Shulte (2011): Governing } \\
\text { Wildfire Risks: What Shapes County } \\
\text { Hazard Mitigation Programs? } \\
\text { - Doan \& Higgins (2011):The Demise of } \\
\text { Queer Space? Resurgent Gentrification and } \\
\text { the Assimilation of LGBT Neighborhoods. }\end{array}$ \\
\hline $\begin{array}{l}\text { Assessing } \\
\text { Practice }\end{array}$ & $\begin{array}{l}\text { Institutional } \\
\text { barriers to } \\
\text { implementing } \\
\text { sustainability plans } \\
\text { (a view from } \\
\text { experience) }\end{array}$ & $\begin{array}{l}\text { Raises question }+ \\
\text { uses experience/ } \\
\text { extended case as } \\
\text { evidence and } \\
\text { illustration; relates } \\
\text { to theory }\end{array}$ & Varies & $\begin{array}{l}\text { Often based on } \\
\text { funded work but } \\
\text { not itself funded } \\
\text { at a high level }\end{array}$ & $\begin{array}{l}\text { Indiv. or } \\
\text { small group }\end{array}$ & $\begin{array}{l}\text { - Frank (2002): Rethinking Planning Theory } \\
\text { for a Master's Level Curriculum. } \\
\text { - Winkler (2011): Retracking Johannesburg : } \\
\text { Spaces for Participation and Policy Making. }\end{array}$ \\
\hline $\begin{array}{l}\text { Enduring } \\
\text { Questions }\end{array}$ & $\begin{array}{l}\text { What makes a city } \\
\text { truly sustainable? }\end{array}$ & $\begin{array}{l}\text { Poses a large } \\
\text { question and/or } \\
\text { object of criticism; } \\
\text { relates to theory; } \\
\text { and proposes ways } \\
\text { forward }\end{array}$ & Long & Low & $\begin{array}{l}\text { Indiv. or } \\
\text { small group }\end{array}$ & $\begin{array}{l}\text { - Beard \& Basolo (2009): Moving Beyond } \\
\text { Crisis, Crossroads, and the Abyss in the } \\
\text { Disciplinary Formation of Planning. } \\
\text { - Sweet \& Chakars (2010): Identity, Culture, } \\
\text { Land, and Language: Stories of Insurgent } \\
\text { Planning in the Republic of Buryatia, } \\
\text { Russia. }\end{array}$ \\
\hline
\end{tabular}




\section{Scientific Frontiers}

Those who try to push scientific frontiers work in a data-driven world of many people looking at specific information to create fragments of a larger picture. They are contributing to the balance of evidence created by a community of scholars. While not typically "pure" science recognizable by, say, hard-core bench researchers, relative to other work in planning this is the scientific edge. By how much does increasing population density decrease auto use? How (much) does land use change affect specific greenhouse gas production? Such researchers rely on substantial competitive funding, often collaborating with scientists from other fields. They undertake original, and often quite expensive, data collection and analysis.

In terms of outputs most scientific papers answer one narrowly-defined question. Many are short- just a few thousand words. Most assume that the background to the issue is well understood, reporting it only briefly. They typically also assume a high level of statistical knowledge among readers. Longer papers provide more detail about methods and limitations rather than answering an additional question, although in planning journals there are often obligatory paragraphs pointing out practical implications. Some papers do not report results but primarily explain and evaluate methods; a few summarize the results of multiple studies. Methods are typically quantitative. If data is collected from people it is done in a very structured manner, though more qualitative methods may be used to fill important conceptual gaps. Outputs often represent contributions by many team members to conceptualization, data collection, and analysis with all these participants named as authors. This culture is common in areas such as transportation and health where planning overlaps with disciplines such as engineering, nutrition, and exercise science.

Such work can be criticized for being narrow. Some publications may appear to represent the "least publishable unit" (LPU) problem where scholars try to mazimize the number of papers 
by dividing the research into very small parts. To be fair to those working at the scientific frontier however, the LPU problem more frequently represents a misapplication of norms from one culture (scientific), where it works because of the methodological depth paired with the brevity of the papers and shared norms of reporting, to another (e.g. practical applications). Those working at the scientific frontier may be dismissive of other cultures as lacking rigor and focus (see Figure 2). Because they produce a large number of short co-authored papers they may be less impressed by their colleagues' more modest output in terms of numbers of articles, even though the number of pages produced per person by those representing other cultures can be substantial.

Figure 2: Culture Self-descriptions and Critiques

\begin{tabular}{llll}
\hline & $\begin{array}{l}\text { Researcher self descrip- } \\
\text { tion/ internal culture }\end{array}$ & Critique OF others & Critique BY others \\
\hline $\begin{array}{l}\text { Scientific } \\
\text { Frontiers }\end{array}$ & $\begin{array}{l}\text { Adding incrementally to } \\
\text { the body of knowledge }\end{array}$ & $\begin{array}{l}\text { Others lack rigor and } \\
\text { specificity; questions are } \\
\text { too broadly defined }\end{array}$ & $\begin{array}{l}\text { Narrow; naïve about practical } \\
\text { applications }\end{array}$ \\
\hline $\begin{array}{l}\text { Practical } \\
\text { Applications }\end{array}$ & $\begin{array}{l}\text { Helping apply evidence to } \\
\text { practice; research that } \\
\text { makes a difference }\end{array}$ & $\begin{array}{l}\text { Others produce research } \\
\text { that is useless, abstract, } \\
\text { and overly academic }\end{array}$ & $\begin{array}{l}\text { May answer a question but } \\
\text { doesn't advance knowledge } \\
\text { enough; descriptive }\end{array}$ \\
\hline $\begin{array}{l}\text { Assessing } \\
\text { Practice }\end{array}$ & $\begin{array}{l}\text { Providing important } \\
\text { lessons from practice }\end{array}$ & $\begin{array}{l}\text { Others lack grounding in } \\
\text { the real world }\end{array}$ & $\begin{array}{l}\text { Overly reliant on personal } \\
\text { experience or cases that may } \\
\text { not apply to other situations; } \\
\text { self-promoting or overly } \\
\text { positive about cases }\end{array}$ \\
\hline $\begin{array}{l}\text { Enduring } \\
\text { Questions }\end{array}$ & $\begin{array}{l}\text { Providing new insights on } \\
\text { fundamental questions, } \\
\text { including ethical concerns }\end{array}$ & $\begin{array}{l}\text { Others answer small } \\
\text { and/or unimportant } \\
\text { questions }\end{array}$ & $\begin{array}{l}\text { This heen done before; } \\
\text { critiques oversimplify; } \\
\text { posturing }\end{array}$ \\
\hline
\end{tabular}

\section{Practical Applications}

Planning researchers wanting to influence the world are often drawn to practically relevant topics. In contrast to those working at the scientific frontier, those looking at practical applications may have looser research designs. Papers typically examine three aspects of current problems in planning: what is the state of current knowledge in that area, what is the evidence 
from this research project, and how can it apply to planning? To do only two of those things, unless done at great depth, makes a very "thin" paper.

Those in this camp may do empirical studies or translate the more technical research of others into lessons for practice. They often use mixed methods and rely on case studies. They may deal with quite messy data. Some larger grants have this kind of research bundled into a bigger project as part of project design or evaluation but many papers are written with only modest funding. Some work overlaps with the scientific camp (e.g. Grengs et al. 2010). While collaboration is common among the practical group, teams are typically smaller than those working at the scientific frontier. Few papers are as short as those produced by those on the scientific frontier.

Researchers in this tradition see themselves as clearly making a difference in areas like housing, community development, urban design, transportation, or land use. Most interact at least informally with the users of their findings to generate ideas, get feedback, and disseminate findings. Others may have formal relationships with agencies that fund their work, or communities who collaborate in it, and such relationships at least partly shape the products. Their work is likely to be fairly easily appreciated by practicing planners or the public. On the other hand practitioners themselves investigate issues, creating briefing papers and descriptive case studies. They often see such activities as "research" even though it may not fulfill the criteria of contribution to knowledge, peer review, recognition of alternative explanations, and the like. Planning researchers need to make a case in terms of the value they add through doing formal research.

Researchers in this camp may see other research as overly arcane, impractical, or bogged down in methodological nuance. In turn, however, they may be seen as too focused on application, planning technicalities, or specific cases and likely to miss the big picture. Those 
working in this area often produce other outputs apart from journal articles and scholarly books - these include reports, manuals, magazine articles, professional conference presentations, and other similar work aimed at influencing planning practice. Certainly these products can draw on, or form the basis of, journal articles. In a world where text may need to be completely rewritten to avoid counting as prior publication of results, however, this duplication is time consuming.

\section{Assessing Practice}

Those assessing practice go the other way to practical application; a researcher practices, or studies prior practice intensively, then reflects. To reflect on one's own practice one needs a foot in both the research and practice camps and the number of those who do this is fairly small. Many accounts of practice are largely descriptive rather than reflective or evaluative and thus do not qualify as research.

However, those who reflect on the closely-examined practice of others-as in a number of works of planning history or other case-studies - enlarge this category.

The area of practice assessments most typically has a low people-to-problem ratio, with researchers spread out among available topics. This is not a simple research culture, however. When reflecting on one's own practice, one has to engage in a project for a substantial time and also step back enough to critically appraise the project. It can be difficult to truly reflect and still maintain relationships with the professionals or wider communities with whom one is working. It may be easier for academics who practice to contribute to work on practical applications rather than reflective practice. Even those preparing historical or case study accounts need to enter into the situations enough to clearly understand the various moving parts, something that takes a great deal of time. 
Conceptually this category makes a lot of sense but it is not as common as one might imagine (Myers 2009). It is often published in book form, for example Krumholz and Forester's (1990) Making Equity Planning Work. Journal publication may occur in specialist outlets rather than outlets such as JPER. Journals in many subareas of planning carry practice notes, planning history deals with such topics, and many academics who combine practice with teaching publish in service learning or participatory action research journals.

People who do research within this culture may be frustrated by other scholars who lack grounding in the world of practical planning or an in-depth understanding of how practice occurs. On the other hand planning academics have often been involved with really good projects, or choose to study them, but in recounting their actual strengths may be seen as too positive by their academic peers. The strength of this work — that it is rich and specific — is also a weakness if others think the findings do not translate well to other situations. Given the time-consuming nature of much of this work, researchers tend to produce a smaller number of qualitatively rich outputs, often written as individuals. They may seem unproductive to colleagues unfamiliar with the character of this culture.

\section{Enduring Questions}

Those who ask enduring questions in articles and books are interested in the bigger, challenging, and recurring issues of the good and the right, power and values, and the role of planning in the world. As the National Endowment for the Humanities states in its introduction to its enduring questions program: "Enduring questions are questions to which no discipline, field, or profession can lay an exclusive claim. In many cases they predate the formation of the academic disciplines themselves..... They are questions that have more than one plausible or 
compelling answer. They have long held interest for young people, and they allow for a special, intense dialogue across generations" (NEH 2010).

Planners take on a somewhat narrower set of questions than the NEH quote implies, but still broad enough, and typically normative (Milroy 2009). What is the good city? To whom are planners ultimately responsible? What are the justifications for planning? Is it possible to have a general theory of urban change? Is planning a discipline? Does participatory planning oppress? What are the implications of specific social, political, economic, and philosophical theories for planning activities?

Planning has a long tradition of answering such questions through proposals for better practice, for example theoretical models such as advocacy, radical, and rational planning. Some answers take the form of provocative critiques of planning. Whether work of this kind represents research or the broader category of scholarship is a matter of some debate. Of course scholarly work can be very important to a field, so even if such work is scholarship and not research it may have an important impact. ${ }^{v}$ However such distinctions may matter when, for example, promotion criteria specify the need for faculty members to conduct research rather than perform creative and scholarly work. As noted above, to be classed as scholarship such work needs to demonstrate expertise, clarity of goals and methods, internal critique, and broad significance. Research, in addition, needs to publicly contribute to knowledge by building on earlier work, systematically collecting and analyzing data, evaluating findings, and engaging alternative explanations. Clearly a large body of work answering enduring questions does qualify as research—particularly using methods of logical argumentation to develop theory (Groat and Wang 2002; Forsyth and Crewe 2006; Goldstein and Carmin 2006).

Much of this work has a low people-to-problem ratio-with researchers dividing up the research landscape. However, there are some hot topics—-for example in planning theory— 
where a number of researchers focus on related questions. While theory is prominent in this culture, some works of history take this form.

Such questions are often dealt with in books or longer articles and chapters. For example, books called The Good City have been published by Jacobs (2011), Donnison (1980) and Lynch (1984 - actually Good City Form). There is also a subset of such work on enduring questions in planning education - for example, what do planners need to know (Edwards and Bates 2011; Alexander 2001)? Writing is typically done alone or in pairs and extensive background is often provided in written outputs.

Those answering enduring questions see themselves as dealing with the important topics of the profession and making substantial contributions to planning thought. They may be much cited and have great influence in academic circles, with work set in course syllabi and debated at conferences and in the pages of journals. To others, however, such researchers may seem bogged down in questions that can never be really answered and that may not have much practical importance.

\section{Planning Research Styles versus Research Cultures}

Several authors have attempted to engage with important distinctions in styles or designs of planning research with implications for the cultural conflicts identified in this paper. Goldstein and Carmin's review of articles in JAPA identified 10 styles of research and scholarship in planning (Goldstein and Carmin 2006). ${ }^{\text {vi }}$ They proposed that over a 40-year period JAPA's articles have become more empirical, suggesting convergence in style. In the same year a different paper used similar methods to identify five styles of environmental design research, in this case reviewing a decade of work in each of six journals, not including JAPA (Forsyth and Crewe 2006). 
Unsurprisingly, there is a great deal of overlap between the two categorizations though Goldstein and Carmin included some types of papers that were not necessarily research-based (e.g. opinion pieces, explication/instruction). Conversely Forsyth and Crewe (2006) pointed to a very small subset of design practice that could be considered to be research (e.g. building prototypes). Figure 3 combines the two typologies into four research style categories—omitting the non-research and design categories mentioned above--and compares these with the research cultures discussed in this paper. Notes below the table indicate the categories in the two sources that were combined into these four major research styles.

\section{Figure 3: Research Styles Versus Research Cultures}

\begin{tabular}{lllll}
\hline $\begin{array}{l}\text { Research Style (Down) vs. Research } \\
\text { Culture (Across) }\end{array}$ & $\begin{array}{l}\text { Scientific } \\
\text { Frontiers }\end{array}$ & $\begin{array}{l}\text { Practical } \\
\text { Applications }\end{array}$ & $\begin{array}{l}\text { Assessing } \\
\text { Practice }\end{array}$ & $\begin{array}{l}\text { Enduring } \\
\text { Questions }\end{array}$ \\
\hline Empirical $^{1}$ & $\boldsymbol{x} \boldsymbol{x}$ & $\boldsymbol{x} \boldsymbol{x}$ & $\boldsymbol{x} \boldsymbol{x}$ & $\mathbf{x}$ \\
\hline Logical argumentation/theory $^{2}$ & $\boldsymbol{x}$ & & $\boldsymbol{x}$ & $\boldsymbol{x} \boldsymbol{x}$ \\
\hline Critical/interpretive $^{3}$ & $\boldsymbol{x}$ & $\boldsymbol{x}$ & $\boldsymbol{x} \boldsymbol{x}$ \\
\hline Synthesis & & & $\boldsymbol{x}$ \\
\hline $\begin{array}{l}\text { XX }=\text { major overlap, } X=\text { minor overlap } \\
\text { Notes: The research styles above summarize those in Goldstein and Carmin (2006) (GC) and Forsyth } \\
\text { and Crewe (2006 (FC). }\end{array}$ & & \\
1. GC: Description, Explanation, Exploration, Evaluation; FC Standard empirical studies \\
2. GC: Theory Building, Recommendation; FC: Logical argumentations \\
3. GC: Interpretation; FC: Critical analyses \\
4.GC and FC :Synthesis
\end{tabular}

As can be seen from the pattern of overlaps (indicated with "x"s) research styles and research culture are not directly related — for example basically every culture has some empirical work. Research styles focus on differences in methods such as empirically based work, logical arguments, criticisms and interpretations that develop the field, and works of synthesis that draw together findings. In contrast, research cultures are distinguished by the scope, character, and audience of contributions. 


\section{Conclusions}

Planning scholarship is diverse and as with many situations where there are differences, there may be misunderstandings and conflicts over what I have called research culture. The clash is not at the base of it a clash of competing research designs or styles, a conflict between specific methods, or even divisions between planning specialties. It is a clash in the ambition and character of questions that planning scholars ask with implications for the range and focus of their work and ultimately for what constitutes a contribution. These are at least partly political questions about what kinds of research can make a difference in the world, which audiences it should address, and about how to make a substantial addition to knowledge.

These distinctions represent significant differences. Information that one culture sees as important data may be merely unimportant "noise" in another (Hirschman 1970; Becher and Trowler 2001). The results of a paper may seem trivial, vague, or ungrounded to those working in a different mode. While there have been a number of useful proposals made for valuing the multiple aspects of planning faculty members' work, these have largely treated research as a single type of output even when proposing different ways of evaluating it (Stiftel et al. 2009).

In a sense having such conflicts is fine, just part of academic diversity. However, the reason I have written this paper is because I sense that this situation is holding back careers and potentially departments. Too often I hear people dismiss work of another culture just because it is different; or loudly laud work that represents the culture they prefer. In contrast others, perhaps intending to be open minded or due to time constraints, allow low-quality work from a different camp to go unchallenged or even praise it. Both responses represent problems.

What then can be done? Answers to this question come in several levels. 
- In terms of education, it is important that doctoral students be exposed to strengths and weaknesses of multiple camps. While this is routine in some departments, it is not universal. Early in a research career it can be difficult to navigate the complex landscape of cultures and it can be comforting to quickly find a home in one. Critiques may be outdated. For example, students reading classic critiques of science may not realize that those taking a more scientific culture have read those critiques too and became more sophisticated. Helping students navigate this with a more open mind should be a task of faculty.

- Among faculty it is more of a challenge to change the dynamic. Those who are avid proponents of one culture may feel their own culture is not well appreciated by colleagues. They may be helped by others demonstrating appreciation (preferably before a crisis in hiring or promotion). Those who claim to be unable to judge alternative cultures need to put in at least a little time to reach beyond their own interests. There are numerous models. For example, many landscape architecture programs are in agriculture colleges and have had to find ways of translating their scholarly productivity into terms understandable by bench scientists.

Overall, academic planning is still evolving. Given the current global challenges in cities and regions, challenges that require different forms of knowledge to solve them and that cross different substantive fields, planning is well positioned to take an important role because of its internal diversity. Work representing different research cultures can contribute to such solutions in complementary ways. However, planning research also takes place in specific places, commonly university departments (Barnes 2004). How the people in those departments value and judge each other's work has important implications for how they nurture contributions to the field. Understanding planning research's diversity can be a first step toward making better judgments. 


\section{References}

Alexander, E. R. 2001. What do planners need to know? Journal of Planning Education and Research 20 (3): 376-80.

Barnes, T. 2004. Placing ideas: genius loci, heterotopia and geography's quantitative revolution. Progress in Human Geography 28, 5: 565-595.

Beauregard, R. 2001. The multiplicities of planning. Journal of Planning Education and Research 20: 437-439.

Beard, V. and V. Basolo. 2009. Moving beyond crisis, crossroads, and the abyss in the disciplinary formation of planning. Journal of Planning Education and Research 29: 233242.

Becher, T. and P.R. Trowler. 2001. Academic Tribes and Territories. Second Edition. Buckingham, UK: The Society for Research into Higher Education and Open University Press.

Birch, E. 2001. Practitioners and the art of planning. Journal of Planning Education and Research 20, 4: 407-422.

Boyer, E. 1990. Scholarship Reconsidered: Priorities of the Professoriate. Menlo Park, CA: Carnegie Foundation for the Advancement of Teaching.

Checkoway, B. 1998 Professionally related public service as applied scholarship, Journal of Planning Education and Research 17(4): 358-360

Doan, P. and H. Higgins. 2011. The demise of queer space? resurgent gentrification and the assimilation of lgbt neighborhoods. Journal of Planning Education and Research 31: 625.

Donnison, D. 1980. The Good City: A Study of Urban Development Policy in Britain. London: Heinmann. 
DuToit, J.L. 2010. A Typology of Designs for Social Research in the Built Environment.

Dissertation presented for the degree of Doctor of Philosophy (Social Science Methods) at the University of Stellenbosch

Edwards, M. and L. Bates. 2011. Planning's core curriculum: knowledge, practice, and implementation. Journal of Planning Education and Research 31: 172-183.

Forsyth, A. \& Crewe, K. 2006. Research in environmental design: definitions and limits. Journal of Architectural and Planning Research 23 (2): 160-175.

Frank, N. 2002. Rethinking planning theory for a master's-level curriculum. Journal of Planning Education and Research 21: 323-330.

Goldstein, H. and J. Carmin. 2006. Compact, diffuse, or would-be discipline? assessing cohesion in planning scholarship, 1963-2002. Journal of Planning Education and Research 26: 6679.

Goldstein, H., and G. Maier. 2010. The use and valuation of journals in planning scholarship: peer assessment versus impact factors. Journal of Planning Education and Research 30 (1): 66-75.

Grengs, J., J. Levine, Q. Shen. Q. Shen. 2010. Intermetropolitan comparison of transportation accessibility: sorting out mobility and proximity in San Francisco and Washington, D.C. Journal of Planning Education and Research 29 (4): 427-443.

Groat, L. and D. Wang. 2002. Architectural Research Methods. New York: John Wiley.

Guhathakurta, S. and P. Gober. 2010. Residential land use, the urban heat island, and water use in Phoenix: a path analysis. Journal of Planning Education and Research 30: 40-51

Hack. G. 1984. Research for urban design. In Architectural Research, James Snyder ed. New York: Van Nostrand Reinhold. 
Hirschman, A.O. 1970. The search for paradigms as a hindrance to understanding. World Politics 22, 3: 329-343.

Hopkins, L. (2001). Planning as science. Journal of Planning Education and Research 20, 4 : 399-406.

Jacobs, A. 2011. The Good City: Reflections and Imaginations. New York: Routledge.

Krumholz, N. And J. Forester. 1990. Making Equity Planning Work. Philadelphia: Temple University Press.

Kuhn, T. 1962. The Structure of Scientific Revolutions. Chicago: University of Chicago Press.

Latour, B. 1981. Insiders and outsiders in the sociology of science; or, how can we foster agnosticism. Knowledge and Society 3: 199-216.

Lynch, K. 1984. Good City Form. Cambridge, MA: MIT Press.

Milroy, B.M. 2009. Planning as a discipline or a field of practice? Journal of Planning Education and Research 29: 243-244.

Muller, B and S. Schulte. 2011. Governing wildfire risks: what shapes county hazard mitigation programs? Journal of Planning Education and Research 31: 60-73.

Myers, D. 2009. Reconsidering planning practice and social theory in our disciplinary formation. Journal of Planning Education and Research 29: 245-246.

Myers, D., \& Kitsuse, A. 2000. Constructing the future in planning: A survey of theories and tools. Journal of Planning Education and Research, 19, 221-231.

NEH (National Endowment for the Humanities). 2010. Enduring Questions (web page). http://www.neh.gov/grants/guidelines/EnduringQuestions.html 
Punter, J., and H. Campbell. 2009. Reflections on the 2008 United Kingdom Research Assessment Exercise for Town and Country Planning and loosely associated disciplines. Town Planning Review 80 (1): 31-55.

Ragin, C.C. 1994. Constructing Social Research. Thousand Oaks, CA: Pine Forge Press.

Raja, S. L. Yin, J. Roemmich, C. Ma, L. Epstein, P. Yaday, and A.B. Ticoalu. 2010. Food environment, built environment, and women's bmi: evidence from Erie County, New York. Journal of Planning Education and Research 29: 444-460.

Rayer, S. and S. K. Smith. 2010. Factors affecting the accuracy of subcounty population forecasts. Journal of Planning Education and Research 30: 147-161.

Rice, R.E. 2002. Beyond Scholarship Reconsidered: Toward an Enlarged Vision of the Scholarly Work of Faculty Members. In Scholarship in the Postmodern Era, Kenneth Zahorski ed. San Francisco: Jossey Bass.

Salet, W. and R. Boer. 2011. Comparing the use and valuation of journals between U.S. and European planning scholars. Journal of Planning Education and Research 31, 1: 95-97.

Siemiatycki, M. 2012. The role of the planning scholar: research, conflict and social change. Journal of Planning Education and Research 32, 2: [ADD PAGES].

Stiftel, B., A. Forsyth, L. Dalton, and F. Steiner. 2009. Assessing planning school performance: multiple paths, multiple measures. Journal of Planning Education and Research 28: 323335.

Swales, J. 2004. Research Genres. Cambridge: Cambridge University Press.

Sweet, E.L. and M. Chakars. 2010. Identity, culture, land, and language: stories of insurgent planning in the Republic of Buryatia, Russia. Journal of Planning Education and Research 30: 198-209. 
Thrift, N.J. 1999. Steps to an ecology of place. In D. Massey, J. Allen, and P. Sarre eds. Human Geography Today. Cambridge: Polity.

Toulmin, S. 1972. Human Understanding. Princeton, NJ: Princeton University Press.

Winkler, T. Retracking Johannesburg: spaces for participation and policy making. Journal of Planning Education and Research 32: 258-271.

${ }^{\mathrm{i}}$ I use the term culture but experimented with a number of other terms including "approach," “camp," "type," "narrative," "agenda," "mode," and "contribution."

ii The convergent character of planning means that concepts such as "disciplinary paradigms" are less relevant than in convergent disciplines, though of course specialty areas may have something akin to a paradigm (Kuhn 1962).

iii Becher and Trowler (2001) use the terms "urban" and "rural" to distinguish between fields with high and low people-to-problem ratios. As reviewers pointed out, this metaphorical use of the words urban and rural may be confusing to planners so I have not used it in the paper.

iv JPER articles have a certain similarity in length, format, and intended audience. The variety of outputs in the table would be far greater with examples from specialist journals or book publishers.

${ }^{\mathrm{v}}$ Of course it is also possible to ask the same question of the other research cultures-for example is a research output merely a scholarly approach to assessing practice? However it is most likely to be asked of work answering enduring questions.

${ }^{\text {vi }}$ Taking a slightly different approach, and drawing on Toulmin (1972) Goldstein and Carmin propose that disciplines may be scientific (aiming to explain) or technical (focused on creating "designs, recipes, techniques, instruments, procedures, institutions, and policies" including "the ongoing emphasis on promoting social equity and solving urban and environmental problems") (Goldstein and Carmin 2006, 68). Planning has some of both dimensions. 